\title{
Santri Perception to Islamic Bank: Are there no Differences with Conventional Banks?
}

\author{
doi.org/10.18196/afkaruna.v17i2.12752
}

\section{Fuad Hadziq}

Universitas Terbuka

fuadhadziq@ecampus.ut.ac.id

\section{Yosi Mardoni}

Universitas Terbuka

yosimardoni@ecampus.ut.ac.id

\section{Moh. Khoirul Anam}

Universitas Muhammadiyah Jakarta

m.khoirulanam@umj.ac.id

\begin{abstract}
Several studies show no difference in practice and academics in general between Islamic banks and conventional banks. However, they are both very different. This research analysed the perceptions of santri/students of Islamic boarding schools regarding no differences between Islamic banks and conventional banks. This research was quantitative with an in-depth descriptive analysis. The research sample used a blend of purposive and judgment techniques applied to santri from several large Islamic boarding schools in Banyuwangi. The analytical method used a two-way causative relationship using multiple regression. The research used a structured questionnaire with a Likert scale and in-depth interviews with santri. Santri's view of Islamic banks differed from that of regular banks. Santri strongly believes in Islamic banking, while the majority is not traditional but represents Islamic ideals. Islamic bank workers, nevertheless, have shown Islam's greater identity than standard banks and imply that no disparities in Islamic banks are shown to be stigmatic.

Keywords: Conventional Bank, Islamic Bank; Perception, Santri, Banyuwangi
\end{abstract}




\section{ABSTRAK}

Beberapa penelitian menunjukkan bahwa tidak ada perbedaan secara umum antara bank syariah dan bank konvensional. Namun, keduanya sangat berbeda. Penelitian ini menganalisis persepsi santri pondok pesantren tentang tidak ada perbedaan antara bank syariah dan bank konvensional. Metode penelitian ini adalah penelitian kuantitatif dengan analisis deskriptif mendalam. Sampel penelitian menggunakan perpaduan teknik purposive dan judgement; santri dari beberapa pondok pesantren besar di Banyuwangi. Metode analisis menggunakan hubungan kausatif dua arah dengan menggunakan regresi berganda. Penelitian ini menggunakan kuesioner terstruktur dengan skala Likert dan wawancara mendalam dengan santri. Pandangan Santri terhadap bank syariah berbeda dengan bank biasa. Santri sangat percaya pada perbankan syariah, sementara mayoritas tidak tradisional tetapi mewakili cita-cita Islam. Pekerja bank Islam, bagaimanapun, telah menunjukkan identitas Islam yang lebih besar daripada bank standar. Ini menyiratkan bahwa tidak ada disparitas di bank syariah yang terbukti bersifat stigma. Keywords: Bank Islam; Bank Konvensional, Persepsi, Santri, Banyuwangi

\section{INTRODUCTION}

Islamic banks have $80 \%$ of a whole financial system's potential market share. ${ }^{1}$ Over the last 26 years, the Indonesian economy has been made a major contribution, although growth was not sufficiently high. The Islamic Bank is one of Indonesia's major Muslim countries in the world as a pioneering contribution. ${ }^{2}$ Indonesia is the largest Muslim country globally, with Muslims representing 88 percent of the population, somewhere in the range of 165 million. ${ }^{3}$ Today, the Muslims number exceeds 165 million due to the growth of the population up to 271 million. ${ }^{4}$

In the world, Islamic banking has increasingly received significant attention. After several economic crises in 1998 and 2009, the effect was almost evenly distributed globally. Conventional banks experienced a more significant negative effect than the Islamic banking sector caused by the global economic crisis. ${ }^{5}$ From a sample of 34 Islamic banks and 34 conventional banks in 16 countries, there was no significant difference in the effect of the financial crisis on Islamic banks and conventional banks. ${ }^{6}$ An Islamic bank captive market is a safe place during difficult financial times. $^{7}$ 
FIGURE 1. Image of market share of Indonesian Islamic Banking

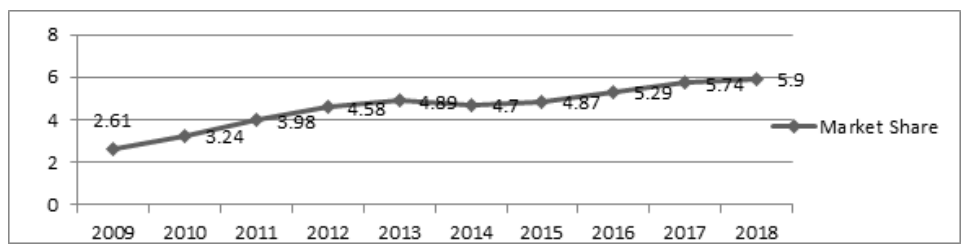

Source: Publication of Bank Indonesia Sharia Financial Progress Report ${ }^{8}$

Based on the image, the Market share of Islamic banking in Indonesia increases, although not too significant. The Market share of Islamic Banking is $5.9 \%$ of total bank assets nationally. ${ }^{9}$ At the same time, the number of customers of Islamic banks is still less than 10 million. As of January 2019, the number of Sharia Commercial Bank was 13 banks, 22 Islamic Business Units, 163 Sharia Credit Bank, and 2,950 office networks. The total assets of the Islamic commercial bank and Islamic business unit are IDR. 316,691 trillion, financing of IDR. 196,491 trillion, and collection of Islamic banking deposits until IDR 207,121 trillion. It can be concluded that the growth of Islamic market share was increasing, little by little but sure to develop year to year. Lately, due to the backup from the government, the growth of Islamic banks will be bigger in the future.

FIGURE 1. Image of market share of Indonesian Islamic Banking

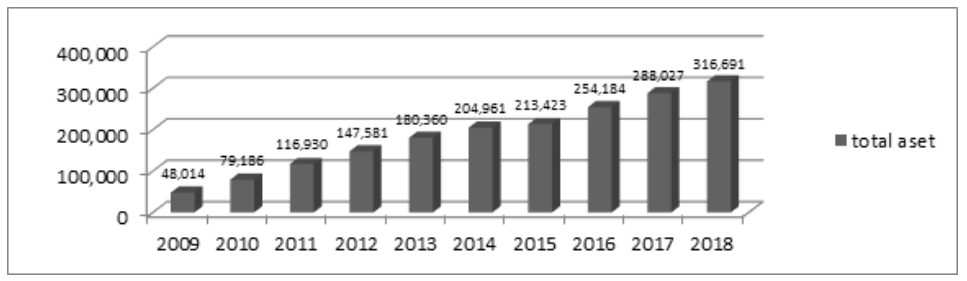

Source: Publication of Sharia Financial Progress Report ${ }^{10}$

The growth of Indonesian Islamic Banking Asset is continuously increasing significantly year by year. Slow but sure, it has the potential to be a big asset bank in Indonesia (Bank Indonesia, 2019). The small market share is only $4.70 \%$ of national banking. Besides the appropriate rate of growth, Indonesia has a considerable market. It is a significant asset of 
the Indonesian economy, especially Muslims. Although the growth is still not as fast as expected, it continues to experience development from year to year, even though it is under the expected plan.

The citizen of Indonesia is predominantly Muslim. At the same time, the largest religious community organisation is Nahdhotul Ulama (NU). ${ }^{11} \mathrm{NU}$ is the largest mass organisation in East Java, especially in Banyuwangi. NU claims to have \pm 40 million members in Indonesia and is the largest religious organisation. Looking at the quantity, ideally, the contribution to the Islamic economy is also substantial, especially from the NU Cultural grass-root in rural areas, especially the main base, which has 27,218 pesantren (an Islamic boarding school in Indonesia) with the number of santri (student) reaching $3,642,738$ people. ${ }^{12}$ The statement was linearly related to the majority population in East Java and Banyuwangi, mostly NU. The majority of pesantren stayed in the village, while the rest is in the downtown. NU is influential in the village with support from pesantren. Accordingly, Banyuwangi has the same characteristic as East Java and Indonesia.

Despite all of those things, a lot of concerns are addressed to Islamic banks. The pesantren politicians still do not believe that Islamic banks are different from normal banks. The notion of Islamic banking as a whole is not yet understood by the majority. With the growth of Islamic banks, administrative and surveillance measures which require Islamic institutions have not yet been established. ${ }^{13}$ Many still think that profit-sharing is the same as interest in conventional banks. They claim profit-sharing is only a derivative of the interest system. Similarly, some research ${ }^{14}$ is still ignorant of the concept and operation of profit sharing. Almost all pesantren live in the village and cannot easily access sharia bank. Only a few pesantren have access to ATM or sharia bank office. Many parents experienced difficulty sending money to their son in pesantren. Consequently, not many rural communities use Sharia bank products because they are not familiar with Sharia banks and cannot reach their services. ${ }^{15}$

Many still believe that the name of a normal bank has been extended by Islamic institutions. A research of the banking ideas and practices of Sharia banks and other Islamic financial institutions in India was one of 
the assumptions of the Executive Board of Nahdlatul Ulama (PBNU). Bank and financial services transactions complementing the word sharia move away from Muamalah fiqh. ${ }^{16}$ There was a diversity of community perceptions of Sharia banks. ${ }^{17}$ Most of the respondents, $55 \%$ of the people, said that Sharia banks are lawful. It was supported by some scholars and santri, who stated that the interest of the legal bank was halal. Of the total respondents, 60 of whom only $10 \%$ said it was haram, the rest said they were syubhat, and the rest had no idea. Previous research stated that Islamic boarding school students in urban areas perceive Sharia banks mostly through TV with 36\% and from Islamic boarding schools $18 \%$. Only $39 \%$ of students become customers of Sharia banks. ${ }^{18}$ In the community of santri, knowledge of sharia banking influenced the use of the saving product. ${ }^{19}$ From these findings, there are indications that the community does not fully understand the existence of a Sharia bank. ${ }^{20}$ This research is necessary to analyse the perception of santri to Sharia banking because they were the candidate of Islamic leaders.

Referring to the terminology, Sharia banks and conventional banks are very different. According to regulations, the difference is in the implementation principle regarding its relation to sharia principles. Sharia banks are operationally different from conventional banks. ${ }^{21}$ In some cases, Sharia banks and conventional banks have similarities, especially the technical ones. However, many fundamental differences between the two concerning legal agreements and legal aspects, dispute resolution institutions, businesses and work environments. These issues distinguished this research from the previous research, which only analyses its legality.

\section{LITERATURE REVIEW}

\section{Perception}

Consumer perception is a process through which a person selects, organizes and interprets the inputs into a meaningful and full world view. ${ }^{22}$ Perception means the individual process selects, organises, and interprets information inputs. The point is to create a picture that has meaning. ${ }^{23}$ It also means the process of how stimuli that influence those 
responses are selected and interpreted. ${ }^{24}$ Each perception of an object varies because perception has a subjective nature. A stimulus can be interpreted as any physical form or verbal communication that can influence individual responses. Likewise, the perception of Sharia banks, a necessary stimulus that can influence consumer behaviour is the environment (social and cultural). The consumer characteristics influence the perception of a Sharia bank consumer to the various stimuli.

The act of choosing, organizing and interpreting the information generates an image with a certain significance or meaning. Accordingly, discrepancies between perceptions between people might be produced by differing capture forces, stages of intelligence and expectancies, which occur in each person based on variables that impact the person's perception..$^{25}$ Likewise, with banks, public perceptions are important for banks in pushing satisfaction ratings, affecting market share, consequently shareholder profits and executive remuneration. ${ }^{26}$ From this opinion, it can be concluded that perception is the process of interpreting and reacting to information received through the five senses.

People might be partially affected by behavior and situation, emotions, attitudes and internal statements. The interpretations of self-perception may be derived from many studies and paradigms in cognitive dissonance literature. Despite that, alternate interpretations of tests cannot be utilized as unambiguous proof of self-perception theory. ${ }^{27}$ Based on the expert's statement, ${ }^{28}$ the perceptual elements are sensations, absolute thresholds and differential thresholds between several different stimuli. A person's perception is influenced by several factors that cause an individual to be able to give a different interpretation than others when they see something. ${ }^{29}$ The factors that influence are functional, structural and cultural that determine perception.

\section{Sharia Banks}

The Sharia Bank's products are essentially separated into three main areas: generating money (funding), the distribution of funds (financing) and services. Free interest and usury, application of zakat, Muslim taxes, lack of produced or consumed illegal products must be strictly applied to 
Islamic financial institutions. ${ }^{30}$ In Indonesia, Sharia banks are regulated in Regulation No. 21 of 2008. Sharia Bank is a bank that runs its business activities based on sharia principles. The Sharia bank consists of Sharia Commercial Banks and Islamic People Financing Banks. Sharia banks, in channeling their funds to stakeholders, are very selective and ensure halal factors. Companies that cooperate with Sharia banks must produce halal goods and services. ${ }^{31}$ Also, Sharia banks will not finance projects containing things Islam prohibits.

In Muamalah, the legal rule is "all transactions are permitted unless there is prohibition." ${ }^{32}$ The prohibition of a transaction can be caused by the haram nature and illegitimate contract. In the case of transacting prohibited goods, the legal transaction is forbidden regardless of the legal sale-purchase agreement. In addition, sharia financial products must meet sharia criteria in avoiding usury, maysir, and gharar. ${ }^{33}$

Sharia banks prohibit tadlis, gharar, ikhtikar, usury, maysir, and riyswah (Info et al., 2019). In addition, various usury is also prohibited in Islamic economics, such as usury fadl, nasi'ah, and jahiliah. Sharia banks contrast from traditional banks mostly in the denial of usury, gharar (over-the-top vulnerability or chance), and illicit exercises (for example, liquor and medications). ${ }^{34}$ At the same time, invalid contracts are when conditions are not fulfilled, taalluq and two contracts at a time. So there is uncertainty about which contract applies.

Sharia banks must have a sharia atmosphere and working culture as Islamic financial organizations. The management of a Sharia Bank has to follow the business concepts based on the examples of the Prophet in his life. It is common (Info et al., 2019) that Sharia banks must follow the principles of shiddiq, amanah, al huriyah and tabligh. Those values must be sustainable in the principles of Sharia banking.

\section{Hypotheses}

The hypothesis is a temporary answer to the formulation of research problems, in which the formulation of research problems has been expressed in the form of questions. ${ }^{35}$ It is a temporary term because the answers are only based on theory. The hypothesis is formulated based on a mindset which is a temporary answer to the problem formulated in 
research. The research hypothesis is that there is a difference between Sharia banks and conventional banks, for example, aqad (riba, prohibition), business (Halal, haram, drugs, alcohol, carcasses, pork) and environment \& work culture (praying, custom, worship).

\section{RESEARCH METHOD}

This quantitative research used numerical data from a closed questionnaire with a Likert scale. This research used questionnaires with indicators and numerical scales. To strengthen the method, in-depth interviews were carried out, especially for data that could not be extracted from regression statistics. Since statistics cannot fully answer problems comprehensively, direct analysis was necessary. The descriptive method in the surveys was in-depth and measurable.

The research used both primary and secondary data. Primary data was collected from direct observation and in-depth interviews, while the secondary data was collected from the library and documentation. Accordingly, a Likert scale was used to measure attitudes, opinions, and perceptions of a person or group on research problems from the research sample.

The sampling used purposive and judgment techniques. The sampling criteria were Islamic boarding schools with the number of santri and alumni above 2000 people, a boarding school branch of at least two pesantren in Indonesia, a branch of at least two pesantren, formal and non-formal education with alumni of at least 2000 santri. Some of the samples taken were from the Darussalam Pesantren Blok Agung Banyuwangi, Pesantren Minhajut Thullab Banyuwangi and the Mambaul Ulum Banyuwangi Islamic Boarding School in Indonesia.

Determination of the number of survey respondents used the Slovin method. The Slovin method, with an error margin of 5\%, obtained 273 respondents. The 273 samples were santri from various large Pesantren in Banyuwangi, Indonesia. Of the 273 samples, 74 were male respondents, 129 were female respondents, and 70 respondents did not fill in the gender column. As for age, 118 respondents were ranging 25-35 years old, 66 respondents ranging 35-45 years, 17 respondents ranging 46-55, 
7 respondents aged over 55 years, and 65 respondents did not fill the age column. The santri were quite mature and understood the development of Sharia banks, even though they did not have updated information. Some obstacles were limited media available, lack of access to technical information and geographical constraints.

Regarding education, 137 respondents were graduated from college, 61 had senior high school grades or equivalent, three were graduated from junior high schools, and 72 respondents did not fill in the education column. The biggest respondents were with bachelor and senior high school degrees.

From the 273 samples, only 43 people with Sharia bank accounts, 57 conventional bank accounts, four both Sharia banks, conventional banks, and 80 without information. It turned out that many santri used conventional banks rather than Sharia banks. It is normal because there are very few Sharia bank offices around the pesantren area. Only one Sharia bank unit in the area is Bank Syariah Mandiri because of its distant location. In addition, the majority of santri use bank services to send money for their daily needs, not for saving or investing. So that, the ownership of the type of bank is still very dependent on the bank used by parents of santri who are from the rural areas far from Sharia banks. The variables studied in this research are :

Table 1. Variable of research

\begin{tabular}{|c|c|c|}
\hline No. & Variable & Indicator \\
\hline 1 & $\begin{array}{l}\text { Aqad \& } \\
\text { Legality }\end{array}$ & $\begin{array}{l}\text { Halal } \\
\text { prohibition } \\
\text { riba } \\
\text { Contract type }\end{array}$ \\
\hline 2 & Business & $\begin{array}{l}\text { Halal } \\
\text { haram } \\
\text { drugs, alcohol, carcasses, pork and others }\end{array}$ \\
\hline 3 & $\begin{array}{l}\text { Environment } \\
\text { and work } \\
\text { culture }\end{array}$ & $\begin{array}{l}\text { How to dress } \\
\text { How to worship } \\
\text { Pray the beginning and end of } \\
\text { Sholat jamaah }\end{array}$ \\
\hline
\end{tabular}

Source: Data processed by researcher 
Lately, the science of using statistics in analysing nesting or hierarchical data is applied by many researchers. ${ }^{36}$ Likewise, this research used multiple linear regression analysis methods by analysing the pattern of relationships between variables to know the direct and indirect effects of the independent and bound variables.

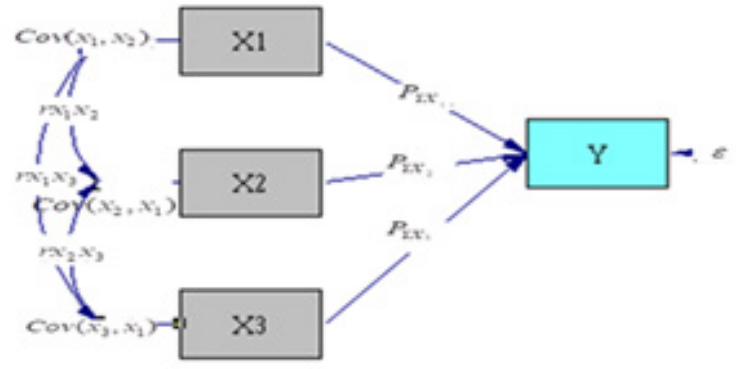

Source: Processed by the author

Figure 3 Relationship scheme between variables and correlations

\section{DISCUSSION}

Data analysis

The data analysis findings discovered in $\mathrm{R}$ square are 0.436. It indicates that 43.6 percent of financial institutions can make up a contract and legal factors, company, environment and working culture. These results show that external influences still impact the impression of Sharia banks rather than internally linked to Sharia banks. Researchers argue that external factors influence people's perceptions of Sharia banks, such as government policies, regulation of the bank of Indonesia and financial services authorities, information and education stakeholder. Santri received much socialisation directly, especially the limited access to the outside world, such as the number of Islamic boarding schools that prohibited technology media from entering Islamic boarding schools such as television, mobile phones, radio, etc.

The results support previous research from the Bank of Indonesia, the Bogor Agricultural Institute (IPB), Diponegoro University, and Brawijaya University Indonesia. The result is that customers' motivation to invest in Sharia banks is influenced by location, service aspects, credibility, facilities, status, knowledge of Sharia banks, rate of return, attitude 
beliefs, work, and education. ${ }^{37}$ The religious orientation of Sharia banking is focused on influencing investors' perceptions. ${ }^{38}$ Based on the coefficient of determination, empirical evidence provides empirical evidence that improving the development of Sharia banking should pay more attention to people's perceptions. Until now, there are still people who have a wrong perception of Sharia banks. However, the perception of Sharia banks is only one variable that can influence investment decisions. Many other factors are more dominant in influencing investment decisions. ${ }^{39}$

The result of the regression model can be stated as follows:

\begin{tabular}{|c|c|c|c|c|c|c|}
\hline & \multirow{2}{*}{ Model } & \multicolumn{2}{|c|}{ Unstandardised Coefficients } & \multirow{2}{*}{$\begin{array}{c}\text { Standardised } \\
\text { Coefficients } \\
\text { Beta }\end{array}$} & \multirow{2}{*}{$\mathrm{t}$} & \multirow{2}{*}{ Sig. } \\
\hline & & B & Std. Error & & & \\
\hline \multirow[t]{4}{*}{1} & (Constant) & .770 & .269 & & 2.858 & .005 \\
\hline & Aqad & .594 & .090 & .357 & 6.589 & .000 \\
\hline & Business & -.222 & .080 & -.139 & -2.791 & .006 \\
\hline & Environmental & .309 & .053 & .323 & 5.871 & .000 \\
\hline
\end{tabular}

Source: Processed data from SPSS

From the regression equation model for the research, the model can be as follows:

$Y=0.770+0.594(X 1)-0.222(X 2)+0.309(X 3)$

\section{Aqad \& legality}

The results of this research Aqad \& Legality have a positive and significant effect on perceptions. The positive influence shows that the perception of students will increase if the contract of Sharia bank products is halal and the contract is in accordance with sharia. This means that the results of this research accept the hypothesis that aqad has a significant effect on students' perceptions. The research results showed that contract variables and legality influence the perceptions of the santri community. Santri tends to be interested in saving at Sharia banks due to religious factors. Sharia banks rely heavily on the depositors' religious commitment in maintaining market share. ${ }^{40}$ Sharia banks need to continue paying attention and maintaining sharia principles as part of sharia compliance, which is a reference in carrying out their operations 
(Info et al., 2019). Pesantren's curriculum follows everything according to the basis of religion, especially in the study of jurisprudence. The law of usury has been explained in the Qur'an and hadith. It is an explicit prohibition; even the prohibition is repeatedly explained in the Qur'an up to four times. Most Islamic religious scholars adhere to the broad interpretation that usury and interest are prohibited. ${ }^{41}$ Santri mostly knows and understands the utility of Islamic products, which can avoid usury in the banking world. When practised the pesantren education, muamalat, halal and haram nature becomes essential.

In the santri community, it is closely synonymous with religious values. Regardless, in Islam, profound quality or morals is dependably hindered by religious qualities. What is religiously commanded constantly turns into an ethical commitment. ${ }^{42}$ It can be said that Banyuwangi, which has a lot of santri, has an economic pattern based on religion. This phenomenon is suitable with previous research that the analysis of factors that motivate people to use Sharia banking services that are more dominant for Central Java Indonesia is a religious consideration factor..$^{43}$ The research response revealed that $94 \%$ of responses stated that Sharia banks guard against things that contain usury. Only $6 \%$ consider usury still carried out by Sharia banks. They were also supported by a $91 \%$ statement of responses stating. Sharia banks have kept their business away from things that contain prohibition in terms of contract and legality. Religious values make santri know about "how to live". They would prioritise all of the world's things because religious values are the first and eminent.

The perception of santri to Sharia banks is very positive. They consider fundamental differences between Sharia banks and conventional banks. Sharia banks are considered still following the provisions in Islamic sharia, both in terms of harmony, contracts and other requirements. It is consistent with research that religious commitment influences people's interest in using Sharia banking products. ${ }^{44}$ Moreover, pesantren are very synonymous with Islamic religious values. In addition, religious guidance has been obligatory in these pesantren. ${ }^{45}$ 
Although many santri still use conventional banks rather than Sharia banks, this research shows that their perception of Sharia banks is still very strong in Islamic values. According to research, ${ }^{46}$ in the respondents, $79.3 \%$ of conventional bank respondents stated bank interest is contrary to the teachings of Islam. They tend to express rejection in the conventional banking system. On the other hand, they are customers of conventional banks, so this can be taken as a perception of consumer behaviour inconsistency. Finally, the previous research results show that understanding consumer behaviour becomes increasingly crucial and needs to be studied.

The majority of santri knows the practice of usury in conventional banks. Conventional bank products, especially financing, are seen by santri as a type of usury. According to research ${ }^{47}$ the boarding school community mostly knows and understands the use of Islamic products. So the hypothesis of the research is accepted. There is a difference between Sharia banks and conventional banks, especially in sharia contracts.

\section{Business}

This research indicates that the business variable has a negative and significant effect. The business has an inverse effect on students' perceptions. The more active business activities, the lower the perception of students. This research accepted the hypothesis that business has a significant effect on students' perceptions.

In business variables, there are three major indicators, namely halal, haram and the business of khamr, pork, carrion, etc. Students' perceptions of banks still perceive that banks do business with illicit products. Santri considers Sharia banks still provide financing to sectors that are not fully halal. Not $100 \%$ halal, meaning that there are still illegal businesses even if they are small. This is a natural and normal thing because, in the field, the fact is that banks provide financing to all types of businesses without exception. Therefore, students can have a bad perception of the halal business of Sharia banks in a kaffah manner.

The research statistic stated that business influence the perceptions of the santri community. The santri respondents consider Sharia banks purely conducting Sharia business, with $81 \%$ stating their perceptions 
agree. Only $19 \%$ of santri respondents still consider santri to disagree. Santri regards Sharia banks in business and product investing as quite distinct from regular banks. Unlike conventional banks, Sharia banks, nevertheless run or fund items that smell as unlawful beverages or haram business, have a clear notion. An expert ${ }^{48}$ argued that Sharia banks operate by not relying on interest. Sharia Banking is everything that concerns Sharia banks and Islamic business units, including institutions, business activities, and the ways and processes in carrying out their business activities. Its means that institutionally Sharia banks make rules about their business activities that must be free from prohibition.

In this research, $78 \%$ of santri respondents stated that they disagreed that Sharia bank business practices were the same as conventional banks. Sharia banks are considered to have very different. Conventional bank perceptions with interest cannot be separated, such as Sharia banks with profit sharing. Sharia banks work on a benefit and misfortune sharing premise contrasted with traditional activities that depend on the premium. ${ }^{49}$ This perception is corroborated by $85 \%$ not agreeing that Sharia banks conduct prohibited sale transactions of goods. Sharia Bank cooperates with companies that are certain to be halal. Sharia banks endeavour to take out the effects of non-halal pay. ${ }^{50}$

In addition to the funding sector, Sharia banks also conduct transactions in the lending sector. In financing Sharia banks that $67 \%$ disagree with Sharia banks; credit members are like credit to conventional banks. In the santri's view, loans given by conventional banks must use interest. From education conducted in Islamic boarding schools, the majority of scholars punish illegitimacy because of usury. Most religious researchers of Islam, be that as it may, hold fast to the comprehensive understanding as indicated by which both usury and intrigue are disallowed. ${ }^{51}$ This stigma is different from the funding made by Sharia banks.

Sharia banks are operationally different from conventional banks, Including in the business. ${ }^{52}$ Especially in a business that is prohibited, such as drugs. Sharia banks also do not provide financing for the company concerned. In this research, it was proven that 240 respondents or $87 \%$, 
drug companies would not be funded or cooperated with Sharia banks. Sharia bank is distinct and clear with drugs because Al Quran prohibits them clearly.

This perception is also the same as the results for companies that are unclear about halal. $87 \%$ of respondents say Sharia banks do not provide financing to companies. Its business process shows that Sharia banks have no major differences in profitability and liquidity from conventional banks. Sharia banks, as new entrants to the financial market, do the same thing with conventional banks. In addition, Sharia banks have a smaller credit risk compared to conventional banks. Their credit performance is superior to conventional banks. ${ }^{53}$

\section{Environmental and work culture}

The attitudes of the santri community are affected by variables and working culture. The beneficial effect of this variable is considerable. This option improves the visibility of students. The investigation results accept the premise of substantial impact on environmental factors. Santri sees workers of Sharia banks as reflecting Islamic principles better than conventional. For Sharia banks, the mean score of these qualities seems greater than regular banks. ${ }^{54}$ Sharia bank employees show more identity Islam than conventional banks. These traits for Sharia banks appear to be higher than those for ordinary banks. ${ }^{55}$ Any values of worship are used in service attributes at the bank office location. The attribute is used starting with Muslim clothes. Every morning before the start of service, it usually starts with reading the Qur'an. This attribute is one form of promotion and socialization to attract customer decisions using Sharia banks. It is consistent with the research ${ }^{56}$ that Muslim consumer behaviour (religious motive and economic motive in the decision-making process) is to carry out socialization and promotion more intensively to provide complete and correct information about Islamic banking business.

Banks are service companies that do not have visible products. There is an influential factor impacting client trust in keeping a money framework. ${ }^{57}$ Therefore, service becomes the attracting factor for customers to be loyal to the bank. Service companies have high trust to determine customer decisions. By ${ }^{58}$, The most dominant consideration in 
choosing conventional banks is the procedure side (fast and easy), dealing with banks, and proximity of location (home and place work) respondent with a bank office. These aspects are more important than the image factors of repute and of banks, the number of banks/branches, collateral for money, bank regulations and availability of banking technology. The consumer preference in selecting conventional banking services is more determined by unrelated factors, such as the need to increase socialisation and promotion of santri, especially within the scope of Islamic behaviour, for quicker and easier procedures, the proximity to a banking site, the reputation of bankers and the number of bank branches. During this period there was, in effect, less large and fair socialisation restricted the expansion of Sharia banks. To conclude from prior research, the core of Sharia banks did not represent many perceptions. There is a large number of unfavorable impressions, but they are generalized in all respects of Sharia banks. This impression gradually develops a powerful and hard-to-remove stigma. The limited knowledge of the community to Sharia banks affects the wrong perceptions, impacting the community's low decision to choose Sharia banks. ${ }^{59}$ It certainly impedes the expansion of the Sharia bank market and inhibits the spread of universal values. Sharia banks need to keep on focusing and keep up sharia standards as a feature of Sharia consistency. ${ }^{60}$ Consecutive socialisation is needed, supported by solid commitments from all Sharia bank human resources to implement Islamic principles.

Therefore Sharia banks need to improve socialisation and education more intensively. ${ }^{61}$ The santri must be more aware of technological advancements. Stakeholders of Sharia banks need to put forward a technological approach to increase public awareness. The santri should follow the development of technology now. Understanding Sharia banks from santri cannot be forever dependent on only religious factors.

Sharia banking should not rely too much on the "spiritual market", which is only filled with loyalist segments of Islam, namely people who choose banks solely for religious reasons. The trend in the future is estimated that the segments cultivated by Sharia banks began to shift from Islamic loyalists to the floating market. Technology development 
causes consumers to be more rational, still prioritising service quality and benefits. It is essential to give experience reaching saving money and good administrations to customers to exploit communication innovation. ${ }^{62}$ Not only from emotional sentiments. Therefore, this tendency needs the readiness of infrastructure and resources owned by Sharia banks today to develop like conventional banks.

\section{CONCLUSION}

Aqad \& lawfulness affect views positively and significantly. This implies that if the Sharia bank contract is halal and the contract is in compliance with Sharia law, the perception of students will grow. The viewpoints of Sharia banks are different from conventional in terms of contract, legality, business and the environment \& work culture of santri. Santri's perspective regarding Sharia banks is extremely good. For his part, they take basic distinctions into account between Islamic and conventional banks. Sharia banks continue to be examined as regards harmony, contracts and other criteria in accordance with the norms of the Islamic sharia. Santri have a strong sense of religious belief in Sharia banks, and yet most of them still utilize regular banks for technical and non-technical reasons. Pesantren's curriculum follows several religious aspects, including the rule of the riba and usurpation. The Sharia activities were conducted.

Then, the business variable has a negative and significant effect. The business has an inverse effect on students' perceptions. The more active business activities, the lower the perception of students. The attitudes of the santri community are affected by variables and working culture. The beneficial effect of this variable is considerable. This option improves the visibility of students. The investigation results accepted the premise of substantial impact on environmental factors. Sharia banks have a clear halal concept and business, contrasted with conventional banks that still provide financing for illegitimate stuff. Sharia banks make rules for their business activities to be free from Islam prohibition. Consequently, many santri perceive that Sharia bank employees better reflect Islamic values than conventional banks because Sharia bank employees show more Islamic identity than those of conventional banks. 


\section{RECOMMENDATION}

The use of IT facilities and social media, particularly the distribution of information to santri in Islamic boarding schools, requires intense and extensive socialization. However, technological media like social media, $\mathrm{TV}$, radio, etc., were banned in many pesantren. They must have actual knowledge of legality, business, the environment and the culture of work. In addition, it is recommended that santri be more conscious of access to technology, in particular in terms of the extent of social media technological growth, because santri has received a lot of non-conventional information from Sharia banks lately.

Sharia banking stakeholders should innovate in the direction of socialization and education, particularly information and profit-sharing. Sharia banks and conventional banks play a significantly distinct role. In Sharia banks' operations and surroundings, ${ }^{63}$ the government should remove regulatory barriers, competition from conventional banks, and the lack of qualified and trained personnel. In addition, authorities and policymakers must review Islamic screening rules. ${ }^{64}$

\section{ENDNOTES}

1 Bank Indonesia, Bank Publication Financial Report (Jakarta, 2019).

2 Minako Sakai, "Women's Studies International Forum Growing Together in Partnership: Women's Views of the Business Practices of an Islamic Savings and Credit Cooperative (Baitul Maal Wat Tamwil) in Central Java, Indonesia," Women's Studies International Forum 33, no. 4 (2010): 412-421.

3 Mohamed Arifff, "Islamic Banking," Asian-Pacific Economic Literature 2, no. 2 (1988): 48-64.

4 BPS, Report, 2020.

5 Santi Dwie Lestari, Hadi Paramu, and Hari Sukarno, "Pengaruh Intellectual Capital Terhadap Kinerja Keuangan Perbankan Syariah Di Indonesia," Ekuitas: Jurnal Ekonomi dan Keuangan 20, no. 3 (2012): 346-366.

6 Khawla Bourkhis and Mahmoud Sami Nabi, "Islamic and Conventional Banks' Soundness during the 2007-2008 Financial Crisis," Review of Financial Economics 22, no. 2 (2013): 68-77.

7 Emrah Ismail Cevik and Mehmet Fatih Bugan, "Regime-Dependent Relation Between Islamic and Conventional Financial Markets," Borsa Istanbul Review 18, no. 2 (2018): 114-121. 
8 Indonesia, Bank Publication Financial Report.

9 Daniel Tri dan Saarce Irawan, "Pengaruh Kegiatan Marketing Terhadap Profitabilitas Dan Nilai Pasar Di Perusahaan Perbankan,” Jurnal Business Accounting, Jurusan Akuntansi Bisnis, UniversitasKristen Petra 3, no. 105020201111002 (2015): 1-12.

10 Indonesia, Bank Publication Financial Report.

11 R. William Liddle, "The Islamic Turn in Indonesia: A Political Explanation,” The Journal of Asian Studies 55, no. 3 (1996): 613-634.

12 Rustam Ibrahim, "Eksistensi Pesantren Salaf Di Tengah Arus Pendidikan Modern,” Jurnal Analisa 21, no. 1 (2014): 253-263.

13 Yusuf Karbhari, Kamal Naser, and Zerrin Shahin, "Problems and Challenges Facing The Islamic Banking System in The West: The Case of The UK," Thunderbird International Business Review 46, no. 5 (2004): 521-543.

14 Misbach Choliq, "Bank Syariah Dan Bank Konvensional," Jurnal Keuangan dan Perbankan 20, no. 1 (2016): 127-140.

15 Eka Apriana, "FAKTOR-FAKTOR YANG MEMPENGARUHI MINAT MASYARAKAT DESA KOTO TALUKMENABUNG DI BANK SYARIAH TELUKKUANTAN KABUPATEN KUANTAN SINGINGI," Juhanperak 2, no. 2 (2021): 434-445.

16 Alhafiz, "PBNU: Bank Berlabel 'Syariah' Di Indonesia Belum Syar'i," Http://Www.Nu.or.Id (Jakarta, 2015).

17 Anita Rahmawaty, "Pengaruh Persepsi Tentang Bank Syari'Ah Terhadap Minat Menggunakan Produk Di Bni Syari'Ah Semarang," Addin 8, no. 1 (2014): 1-28.

18 Any Meilani, "Persepsi Santri Terhadap Bank Syariah," JEBI (Jurnal Ekonomi dan Bisnis Islam) 2, no. 2 (2017): 131-143, http://journal.febi.uinib.ac.id/index.php/jebi/article/view/108.

19 Maskur Rosyid and Halimatu Saidiah, "Pengetahuan Perbankan Syariah Dan Pengaruhnya Terhadap Minat Menabung Santri Dan Guru," ISLAMINOMIC JURNAL Jurnal 7, no. 7 (2016): 37-45.

20 Anita Rahmawaty, Sekolah Tinggi, and Agama Islam Negeri, "Model Adopsi Produk Bank Syari'Ah Di Kudus: Pengembangan Theory of Reasoned Action Dan Syariah Compliance” 309, no. 2 (2014): 309-330.

21 Choliq, "Bank Syariah Dan Bank Konvensional."

22 M.A. Firmansyah, Perilaku Konsumen (Sikap Dan Pemasaran) (DeePublish, 2018).

23 Josefa D Mart, “Tourists' Characteristics and the Perceived Image of Tourist Destinations: A Quantitative Analysis-a Case Study of Lanzarote, Spain,” Tourism Management 25, no. 5 (2004): 623-636.

24 Michael A Webster et al., Adaptation to Natural Facial Categories, vol. 428 (Nature, 2004). 
Sadhana, "Sosialisasi Dan Persepsi Bank Syariah (Kajian Kebijakan Enkulturasi Nilai-Nilai Bank Syariah Dalam Masyarakat)," Jurnal Keuangan dan Perbankan 16, no. 3 (2012): 481-488.

26 Ameeta Jain, John Guo, and Chien-Ting Lin, "Bank Fundamentals, Executive Compensation and Public Perception of Banks in Australia," Economic Papers: A journal of applied economics and policy 33, no. 3 (2014): 220-232.

27 Daryl J Bem, Self-Perception Theory, Advances in Experimental Social Psychology, vol. 6 (Academic Press, 1972).

28 Consumer Behavior Concepts et al., "American Marketing Association" (2015): 1-4.

29 Ary Permatadeny; NEVITA and ARIFIN, "Perilaku, Karakteristik, Persepsi Masyarakat Terhadap Bank Syariah Di Eks Karasidenan Kediri,” Jurnal Nusantara of Research 2, no. 2 (2015).

30 Natalie Schoon, Modern Islamic Banking: Products and Processes in Practice (John Wiley \& Sons, 2016).

31 Shakir Ullah and Dima Jamali $\Psi$, "Institutional Investors and Corporate Social Responsibility: The Role of Islamic Financial Institutions," International Review of Busniess Research Papers 6, no. 1 (2010): 619-630.

32 Noor Mohammad Osmani and Faruk Abdullah, "Towards An Islamic Stock Market: A Review of Classical and Modern Literatures," International Review of Business Research Papers 5, no. 5 (2009): 121-130.

33 Schoon, Modern Islamic Banking: Products and Processes in Practice.

34 Jill Johnes, Marwan Izzeldin, and Vasileios Pappas, "A Comparison of Performance of Islamic and Conventional Banks 2004-2009," Journal of Economic Behavior and Organization 103 (2014): 1-15.

35 Siti Rokhmi Fuadati and Dini Widyawati, "Model Kemampuan Manajerial Mudharib Sebagai Dasar Investasi,” Ekuitas 20, no. 3 (2012): 261-279.

36 Tülin Acar, "Determination of a Differential Item Functioning Procedure Using the Hierarchical Generalized Linear Model: A Comparison Study with Logistic Regression and Likelihood Ratio Procedure," SAGE Open 2, no. 1 (2012): 1-8.

37 (Bank Indonesia, 2000)

38 Marwa Elnahass, Marwan Izzeldin, and Omneya Abdelsalam, "Loan Loss Provisions, Bank Valuations And Discretion: A Comparative Study Between Conventional and Islamic Banks," Journal of Economic Behavior and Organization 103 (2014): 14.

39 Rahmawaty, "Pengaruh Persepsi Tentang Bank Syari'Ah Terhadap Minat Menggunakan Produk Di Bni Syari'Ah Semarang.”

40 K. Parameswara Rao, "Spectrophotometric Method for The Validation of Indinavir in Pharmaceutical Dosage Forms," International Journal of Chemical Sciences 49, no. 2 (2016): 251-277. 
41 Peter A. Cornelisse and Wouter Steffelaar, "Islamic Banking in Practice: The Case of Pakistan,” Development and Change 26, no. 4 (1995): 687-699.

42 Miftachul Huda et al., "Understanding Comprehensive Learning Requirements in the Light of Al-Zarnūjī’s Ta'līm Al-Muta'Allim,” SAGE Open 6, no. 4 (2016): 1-14.

43 Rahmawaty, "Pengaruh Persepsi Tentang Bank Syari'Ah Terhadap Minat Menggunakan Produk Di Bni Syari'Ah Semarang.”

44 Dewi Sartika, Ali Mubarak, and Indari Larasati, "Hubungan Antara “ Religious Commitment' Dengan Keputusan Mengunakan Jasa Bank Syariah Pada Dosen Unisba," Prosiding SNaPP: Sosial, Ekonomi dan Humaniora 2, no. 1 (1999): 437-448.

45 Liddle, "The Islamic Turn in Indonesia: A Political Explanation."

46 Rohmadi, Nurbaiti, and Junaidi, "Analisi Faktor Penentu Keputusan Nasabah Dalam Memilih Jasa Perbankan Syariah Dan Perbankan Konvensional Di Kote Bengkulu,” Jurnal Munhaj 4, no. 3 (2016): 283-290.

47 Achmad Fauzi, "Variabel Yang Mempengaruhi Minat Masyarakat Pesantren Menggunakan Produk Perbankan Syariah Di Daerah Istimewa Yogyakarta," Journal of Economics and Business Aseanomics(JEBA) Volume 2 No. 1, Januari-Juni 2017 2, no. 1 (2017): 1-25.

48 Choliq, "Bank Syariah Dan Bank Konvensional."

49 Hamidah Ramlan and Mohd Sharrizat Adnan, "The Profitability of Islamic and Conventional Bank: Case Study in Malaysia," Procedia Economics and Finance 35 (2016): 359-367.

50 Nur Fitriana Hamsyi, "The Impact of Good Corporate Governance and Sharia Compliance on The Profitability of Indonesia's Sharia Banks," Problems and Perspectives in Management 17, no. 1 (2019): 56-66.

51 Cornelisse and Steffelaar, "Islamic Banking in Practice: The Case of Pakistan."

52 Choliq, "Bank Syariah Dan Bank Konvensional."

53 Abdus Samad, "Performance Of Interest-Free Islamic Banks Vis-À-Vis Interest-Based Conventional Banks Of Bahrain," IIUM Journal of Economics and Management 2, no. 2 (2004): 1-14.

54 Cengiz Erol and Radi El-bdour, "Attitudes, Behaviour and Patronage Factors of Bank Customers Towards Islamic," IJBM 7, no. 6 (1989): 31-37. 55 Ibid.

56 Ibid.

57 Asma Salman and Huma Nawaz, "Islamic Financial System and Conventional Banking: A Comparison,” Arab Economic and Business Journal 13, no. 2 (2018): 155-167.

58 Rohmadi, Nurbaiti, and Junaidi, "Analisi Faktor Penentu Keputusan Nasabah Dalam Memilih Jasa Perbankan Syariah Dan Perbankan Konvensional Di Kote Bengkulu.” 
59 Sadhana, "Sosialisasi Dan Persepsi Bank Syariah (Kajian Kebijakan Enkulturasi Nilai-Nilai Bank Syariah Dalam Masyarakat).”

60 Hamsyi, "The Impact of Good Corporate Governance and Sharia Compliance on The Profitability of Indonesia's Sharia Banks."

61 Moh Khoirul Anam and Lia Anggraini, "Meningkatkan Literasi Perbankan Syariah Dengan Mengembangkan Aplikasi Edukasi Berbasis Android," JUST IT: Jurnal Sistem Informasi, Teknologi Informasi dan Komputer 10, no. 2 (2020): 18-34, https://jurnal.umj.ac.id/index.php/just-it/article/view/53 25.

62 Parameswara Rao, "Spectrophotometric Method for The Validation of Indinavir in Pharmaceutical Dosage Forms."

63 Karbhari, Naser, and Shahin, "Problems and Challenges Facing The Islamic Banking System in The West: The Case of The UK."

64 Cevik and Bugan, "Regime-Dependent Relation Between Islamic and Conventional Financial Markets."

\section{REFERENCES}

Acar, Tülin. "Determination of a Differential Item Functioning Procedure Using the Hierarchical Generalized Linear Model: A Comparison Study with Logistic Regression and Likelihood Ratio Procedure.” SAGE Open 2, no. 1 (2012): 1-8.

Achmad Fauzi. "Variabel Yang Mempengaruhi Minat Masyarakat Pesantren Menggunakan Produk Perbankan Syariah Di Daerah Istimewa Yogyakarta." Journal of Economics and Business Aseanomics (JEBA) Volume 2 No. 1, Januari-Juni 2017 2, no. 1 (2017): 1-25.

Alhafiz. "PBNU: Bank Berlabel 'Syariah' Di Indonesia Belum Syar'i." Http://Www.Nu.or.Id. Jakarta, 2015.

Anam, Moh Khoirul, and Lia Anggraini. "Meningkatkan Literasi Perbankan Syariah Dengan Mengembangkan Aplikasi Edukasi Berbasis Android." JUST IT: Jurnal Sistem Informasi, Teknologi Informasi dan Komputer 10, no. 2 (2020): 18-34 https://jurnal.umj.ac.id/index.php/just-it/article/view/53. 25.

Apriana, Eka. "FAKTOR-FAKTOR YANG MEMPENGARUHI MINAT MASYARAKAT DESA KOTO TALUKMENABUNG DI BANK SYARIAH TELUKKUANTAN KABUPATEN KUANTAN SINGINGI.” Juhanperak 2, no. 2 (2021): 434-445.

Arifff, Mohamed. "Islamic Banking." Asian-Pacific Economic Literature 2, no. 2 (1988): 48-64.

Bem, Daryl J. Self-Perception Theory. Advances in Experimental Social Psychology. Vol. 6. Academic Press, 1972.

Bourkhis, Khawla, and Mahmoud Sami Nabi. "Islamic and Conventional 
Banks' Soundness during the 2007-2008 Financial Crisis." Review of

Financial Economics 22, no. 2 (2013): 68-77.

BPS. Report, 2020

Cevik, Emrah Ismail, and Mehmet Fatih Bugan. "Regime-Dependent Relation

Between Islamic and Conventional Financial Markets." Borsa Istanbul Review 18, no. 2 (2018): 114-121.

Choliq, Misbach. "Bank Syariah Dan Bank Konvensional." Jurnal Keuangan dan

Perbankan 20, no. 1 (2016): 127-140.

Concepts, Consumer Behavior, David L Loudon, Albert J Della Bitta, Carol A

Scott, and John Myers. "American Marketing Association” (2015): 1-4.

Cornelisse, Peter A., and Wouter Steffelaar. "Islamic Banking in Practice: The

Case of Pakistan.” Development and Change 26, no. 4 (1995): 687-699.

Elnahass, Marwa, Marwan Izzeldin, and Omneya Abdelsalam. "Loan Loss

Provisions, Bank Valuations And Discretion: A Comparative Study

Between Conventional and Islamic Banks." Journal of Economic Behavior and Organization 103 (2014): 14.

Erol, Cengiz, and Radi El-bdour. "Attitudes, Behaviour and Patronage Factors of Bank Customers Towards Islamic.” IJBM 7, no. 6 (1989): 31-37.

Firmansyah, M.A. Perilaku Konsumen (Sikap Dan Pemasaran). DeePublish, 2018 Fuadati, Siti Rokhmi, and Dini Widyawati. "Model Kemampuan Manajerial Mudharib Sebagai Dasar Investasi.” Ekuitas 20, no. 3 (2012): 261-279.

Hamsyi, Nur Fitriana. "The Impact of Good Corporate Governance and Sharia Compliance on The Profitability of Indonesia's Sharia Banks." Problems and Perspectives in Management 17, no. 1 (2019): 56-66.

Huda, Miftachul, Jibrail Bin Yusuf, Kamarul Azmi Jasmi, and Gamal Nasir Zakaria. "Understanding Comprehensive Learning Requirements in the Light of Al-Zarnūjī’s Ta'līm Al-Muta'Allim.” SAGE Open 6, no. 4 (2016): $1-14$.

Ibrahim, Rustam. "Eksistensi Pesantren Salaf Di Tengah Arus Pendidikan Modern." Jurnal Analisa 21, no. 1 (2014): 253-263.

Indonesia, Bank. Bank Publication Financial Report. Jakarta, 2019.

-. Penelitian Potensi, Preferensi, Dan Perilaku Masyarakat Terhadap Bank Syariah Di Wilayah Jawa Barat. Bogor: BI dan Lembaga Penelitian IPB, 2000.

Irawan, Daniel Tri dan Saarce. "Pengaruh Kegiatan Marketing Terhadap Profitabilitas Dan Nilai Pasar Di Perusahaan Perbankan.” Jurnal Business Accounting, Jurusan Akuntansi Bisnis, Universitas Kristen Petra 3, no. 105020201111002 (2015): 1-12.

Jain, Ameeta, John Guo, and Chien-Ting Lin. "Bank Fundamentals, Executive Compensation and Public Perception of Banks in Australia." Economic Papers: A journal of applied economics and policy 33, no. 3 (2014): 220-232. 
Johnes, Jill, Marwan Izzeldin, and Vasileios Pappas. "A Comparison of Performance of Islamic and Conventional Banks 2004-2009.” Journal of Economic Behavior and Organization 103 (2014): 1-15.

Karbhari, Yusuf, Kamal Naser, and Zerrin Shahin. "Problems and Challenges Facing The Islamic Banking System in The West: The Case of The UK." Thunderbird International Business Review 46, no. 5 (2004): 521-543.

Lestari, Santi Dwie, Hadi Paramu, and Hari Sukarno. "Pengaruh Intellectual Capital Terhadap Kinerja Keuangan Perbankan Syariah Di Indonesia.” Ekuitas: Jurnal Ekonomi dan Keuangan 20, no. 3 (2012): 346-366.

Liddle, R. William. "The Islamic Turn in Indonesia: A Political Explanation." The Journal of Asian Studies 55, no. 3 (1996): 613-634.

Mart, Josefa D. "Tourists' Characteristics and the Perceived Image of Tourist Destinations: A Quantitative Analysis-a Case Study of Lanzarote, Spain.” Tourism Management 25, no. 5 (2004): 623-636.

Meilani, Any. "Persepsi Santri Terhadap Bank Syariah.” JEBI (Jurnal Ekonomi dan Bisnis Islam) 2, no. 2 (2017): 131-143. http://journal.febi.uinib.ac.id /index.php/jebi/article/view/108.

NEVITA, Ary Permatadeny;, and ARIFIN. "Perilaku, Karakteristik, Persepsi Masyarakat Terhadap Bank Syariah Di Eks Karasidenan Kediri.” Jurnal Nusantara of Research 2, no. 2 (2015).

Osmani, Noor Mohammad, and Faruk Abdullah. "Towards An Islamic Stock Market: A Review of Classical and Modern Literatures." Intertional Review of Business Research Papers 5, no. 5 (2009): 121-130.

Parameswara Rao, K. "Spectrophotometric Method for The Validation of Indinavir in Pharmaceutical Dosage Forms." International Journal of Chemical Sciences 49, no. 2 (2016): 251-277.

Rahmawaty, Anita. "Pengaruh Persepsi Tentang Bank Syari'Ah Terhadap Minat Menggunakan Produk Di Bni Syari'ah Semarang." Addin 8, no. 1 (2014): 1-28.

Rahmawaty, Anita. "Pengaruh Persepsi Tentang Bank Syari'Ah Terhadap Minat Menggunakan Produk Di Bni Syari'ah Semarang.” Addin 8, no. 1 (2014): 1-28.

Ramlan, Hamidah, and Mohd Sharrizat Adnan. "The Profitability of Islamic and Conventional Bank: Case Study in Malaysia." Procedia Economics and Finance 35 (2016): 359-367.

Rohmadi, Nurbaiti, and Junaidi. "Analisi Faktor Penentu Keputusan Nasabah Dalam Memilih Jasa Perbankan Syariah Dan Perbankan Konvensional Di Kote Bengkulu." Jurnal Munhaj 4, no. 3 (2016): 283-290.

Rosyid, Maskur, and Halimatu Saidiah. "Pengetahuan Perbankan Syariah Dan Rosyid, Maskur, and Halimatu Saidiah. "Pengetahuan Perbankan Syariah 
Dan Pengaruhnya Terhadap Minat Menabung Santri Dan Guru.” ISLAMINOMIC JURNAL Jurnal 7, no. 7 (2016): 37-45.

Sadhana. "Sosialisasi Dan Persepsi Bank Syariah (Kajian Kebijakan Enkulturasi

Nilai-Nilai Bank Syariah Dalam Masyarakat).” Jurnal Keuangan dan Perbankan 16, no. 3 (2012): 481-488.

Sakai, Minako. "Women's Studies International Forum Growing Together in Partnership: Women's Views of the Business Practices of an Islamic Savings and Credit Cooperative ( Baitul Maal Wat Tamwil ) in Central Java, Indonesia.” Women's Studies International Forum 33, no. 4 (2010): 412-421.

Salman, Asma, and Huma Nawaz. "Islamic Financial System and Conventional Banking: A Comparison." Arab Economic and Business Journal 13, no. 2 (2018): 155-167.

Samad, Abdus. "Performance Of Interest-Free Islamic Banks Vis-̇̀-Vis Interest-Based Conventional Banks Of Bahrain." IIUM Journal of Economics and Management 2, no. 2 (2004): 1-14.

Sartika, Dewi, Ali Mubarak, and Indari Larasati. "Hubungan Antara 'Religious Commitment' Dengan Keputusan Mengunakan Jasa Bank Syariah Pada Dosen Unisba.” Prosiding SNaPP: Sosial, Ekonomi dan Humaniora 2, no. 1 (1999): 437-448.

Schoon, Natalie. Modern Islamic Banking: Products and Processes in Practice. John Wiley \& Sons, 2016.

Ullah, Shakir, and Dima Jamali $\Psi$. "Institutional Investors and Corporate Social Responsibility: The Role of Islamic Financial Institutions." International Review of Business Research Papers 6, no. 1 (2010): 619-630.

Webster, Michael A, Daniel Kaping, Yoko Mizokami, and Paul Duhamel. Adaptation to Natural Facial Categories. Vol. 428. Nature, 2004. 